\title{
Influence of sex on performance, carcass traits and economic feasibility of cattle fed high grain diets
}

\section{Influência do sexo no desempenho, característica de carcaça e viabilidade econômica de bovinos alimentados com dieta de alto grão}

\author{
Elizângela Oliveira Cardoso ${ }^{1}$; Robério Rodrigues Silva ${ }^{2 *}$; \\ Gleidson Giordano Pinto de Carvalho ${ }^{3}$; Geraldo Trindade Júnior²; \\ Sinvaldo Oliveira de Souza ${ }^{1}$; Mateus de Melo Lisboa ${ }^{1}$; \\ Maria Magna Silva Pereira ${ }^{1}$; Fabrício Bacelar Lima Mendes ${ }^{1}$; \\ Vitor Visintin Silva de Almeida ${ }^{4}$; Aline Cardoso Oliveira ${ }^{4}$
}

\begin{abstract}
This study was aimed at evaluating the effect of gender on performance, carcass traits and economic feasibility of finishing beef cattle fed high grain diets. The experiment was conducted at the Manaus Farm, located in the boroughs of Itajú do Colônia, southern Bahia state. A total of 40 Nellore animals have been used: 20 uncastrated strees and 20 heifers, separated as a function of treatments: males and females have been arranged in a completely randomized design. Except for feed conversion and feed efficiency (FE), there was no statistical difference in performance $(\mathrm{P}>0.05)$. Sex has exerted an effect in all carcass traits $(\mathrm{P}<0.05)$. In cost to taxes, personnel, depreciation, improvements and administration relatedcosts have not varied as a function of sex $(\mathrm{P}>0.05)$. The total cost of males was higher than the females' $(P<0.05)$. Income and profitability did not vary $(\mathrm{P}<0.05)$. Males and females have the same performance when fed diets high grain, however females have better fat cover. Use of male and female high grain in feedlots are economically viable.
\end{abstract}

Key words: Corn, feedlot, meat, sex, ruminant

\section{Resumo}

Objetivou-se avaliar o efeito do sexo sobre o desempenho, as características de carcaça e a viabilidade econômica da terminação de bovinos alimentados com dieta de alto grão. O experimento foi conduzido na fazenda Manaus, municípios de Itajú do Colônia, localizado na região sul da Bahia. Foram utilizados 40 bovinos da raça Nelore, 20 novilhos não castrados e 20 novilhas, separados de acordo com os tratamentos: machos e fêmeas organizados no delineamento inteiramente ao acaso. Não foram observadas diferenças estatísticas de desempenho $(\mathrm{P}>0,05)$, exceto para conversão alimentar e eficiência alimentar $(\mathrm{P}<0,05)$. Houve efeito do sexo para todas as características de carcaça $(\mathrm{P}<0,05)$. Os custos de mão-de-obra, depreciação, benfeitorias, administração e taxas não apresentaram diferenças entre os sexos estudadas $(\mathrm{P}>0,05)$. $\mathrm{O}$ custo total com os machos foi superior ao obtidos para as fêmeas $(\mathrm{P}<0,05)$. Não houve

\footnotetext{
${ }^{1}$ Discentes, Universidade Estadual do Sudoeste da Bahia, UESB, Itapetinga, BA, Brasil. E-mail: eocardoso@hotmail.com; sinvaloliveira79@hotmail.com; teteubahia@hotmail.com; magnasp@hotmail.com; fabricio.bacelar@hotmail.com

2 Profs., UESB, Itapetinga, BA, Brasil. E-mail: rrsilva.uesb@hotmail.com; geraldouesb@yahoo.com.br

${ }^{3}$ Prof., Universidade Federal da Bahia, UFBA, Salvador, BA, Brasil. E-mail: gleidsongiordano@yahoo.com.br

${ }^{4}$ Profs., Universidade Federal de Alagoas, UFAL, Arapiraca, AL, Brasil. E-mail: vsazootec@yahoo.com.br; ninhazootec@ hotmail.com

* Author for correspondence
} 
diferença na rentabilidade e lucratividade $(\mathrm{P}<0,05)$. Machos e fêmeas apresentam mesmo desempenho quando alimentados com dietas de alto grão, no entanto fêmeas apresentam melhor cobertura de gordura. Uso de macho e fêmeas em confinamentos de alto grão são viáveis economicamente.

Palavras-chave: Milho, confinamento, carne, sexo, ruminante

\section{Introduction}

A grain rich diet for feedlot finishing ruminants can be a lucrative alternative even when forage production is in critical conditions. Lopes et al.(2011) have reported that, when one considers the need to reduce slaughter age and/or shorten production cycles, confinement may be an alternative.

The effect of sex has been highly determinant of differences in growth and deposition rates of different body tissues and carcass (BERG; BUTTERFIELD, 1976).

According to Paulino Valadares Filho and Detmann (2009) very little is known about the effect of sex and its interaction with diets of varying energy density on the performance, intake parameters and nutrient digestibility, particularly of Nellore cattle, which represents large portion of the domestic herd. However should be analyzed economic feasibility as well as the applicability of the system in the field.

Amongst other production costs, net income and return on the invested capital are important considerations for the success of any production system (SILVA et al., 2010).

The objective was therefore to evaluate the effect of gender on performance, carcass traits and economic feasibility in the finishing period of feedlot Nellore cattle fed high-grain based diets.

\section{Material and Methods}

The experiment was conducted at the Manaus farm, located in the boroughs of Itajú do Colônia, southern Bahia state, from September to November 2010 .

A total of 40 Nellore animals have been used: 20 uncastrated steers aged 30 months, weighting on average $411 \pm 20.82 \mathrm{~kg}$, and 20 heifers aged 24 months, weighting on average $274 \pm 17.80 \mathrm{~kg}$. The animals were allocated in two $600 \mathrm{~m}^{2}$-enclosures provided with drinking and feeding troughs without roofing. The enclosures had a side access door of $90 \mathrm{~cm}$.

All animals were vaccinated, dewormed and identified before being included in the experiment. Their distribution was carried as a function of the treatments: males and females have been arranged in a completely randomized design.

The experimental period lasted 100 days: 20 days for adaptation to the diet and 80 days for data collection. The adaptation was initiated with $10 \%$ of the total diet, which was gradually increased by $10 \%$ every two days, in line with the staircase method. During this period, the animals have grazed the forage available in their troughs.

The diet consisted of $85 \%$ whole corn grains and $15 \%$ vitaminic-mineral proteinic nucleus. The diet was provided ad libitum and adjusted twice daily for 10\% of leftovers at 8:00 am and 04:00 pm. Samples of the provided food and leftovers were daily collected. After that, the samples were placed in labeled plastic bags and stored for further analysis.

The diet samples were thawed at room temperature and homogenized in such a way that made a composite sample. Next, the samples were packed in disposable aluminum dishes, and pre-dried in an oven with forced ventilation, for 72 hours, at $65^{\circ} \mathrm{C}$. Afterwards, the samples were ground in a Willey mill, sifted through $1 \mathrm{~mm}$ mesh sieves, and subjected to dry matter (DM), organic matter (OM), ash (AS), crude protein (CP), ether extract (EE), neutral detergent fiber corrected for ash and protein (NDFap) and acid detergent fiber (ADF), according 
to Silva and Queiroz (2002).The neutral detergent fiber content corrected for ash and protein (NDFap) was performed as recommended by Hall (2003). The total carbohydrates (TCHE) were obtained using the equation described by Sniffen et al. (1992).

The concentration of non-fiber carbohydrates corrected for ash and protein (NFCap) was calculated as proposed by Hall (2003).

The estimated levels of total digestible nutrients $\left(\mathrm{TDN}_{\mathrm{est}}\right)$ were calculated according to Cappelle et al. (2001).

In order to determine the internal marker, DM and indigestible NDF, the diet samples were incubated in the rumen of two fistulated steers, for $240 \mathrm{~h}$ (CASALI et al., 2008). Waste was the indigestible portion (table 1).

Table 1. Ratio of ingredients and chemical composition in the diet.

\begin{tabular}{lc}
\hline \multicolumn{2}{c}{ Ratio of ingredients (\%) } \\
\hline Whole corn grain & 85 \\
Protein-mineral-vitamin nucleus $^{1}$ & 15 \\
\hline \multicolumn{2}{c}{ Chemical-bromatological composition (\%) } \\
\hline Dry matter & 87.40 \\
Organic Matter & 83.12 \\
Crude Protein & 11.06 \\
Ash & 4.28 \\
Neutral Detergent Fiber Adjusted to Ash and Protein & 29.06 \\
Acid Detergent Fiber & 10.10 \\
Total Carbohydrates & 80.80 \\
Non-Fiber Carbohydrates & 51.74 \\
Ether Extract & 3.85 \\
Estimated Total Digestible Nutrients & 74.41 \\
Indigestible Dry Matter & 26,62 \\
Indigestible Neuter Detergent Fiber & 51,43 \\
\hline
\end{tabular}

Premix composition by $\mathrm{kg}$ of the nucleus: sulfur $-4.5 \mathrm{~g}$; magnesium $-0.7 \mathrm{~g}$; potassium $-2.7 \mathrm{~g}$; sodium $-9.7 \mathrm{~g}$; cobalt $5 \mathrm{mg}$; copper - $175 \mathrm{mg}$; chromium $-1.4 \mathrm{mg}$; fluorine $-130 \mathrm{mg}$; iodine $-5 \mathrm{mg}$; manganese $-182 \mathrm{mg}$; molybdenum $-0.35 \mathrm{mg}$; nickel - $0.3 \mathrm{mg}$; selenium - $1.8 \mathrm{mg}$; zinc $-421 \mathrm{mg}$; vitamin $\mathrm{A}-$ 21000 ui, vitamin D - 3000 ui, vitamin E - 140 ui.

Guarante levels of the nucleus: phosphorus $-1 \%$; calcium $4.3 \%$; ether extract $-1.4 \%$; fiber matter $-6.9 \%$; ash -21.4 ; crude protein $-38.6 \%$; TDN-60\%, NPN-42\%, humidity - 10\%, sodium monensin $-150 \mathrm{mg} / \mathrm{kg}$.

Source: Elaboration of the authors.
At the beginning and at the end of data collection period, the animals were weighed after fasting of solids for 12 hours.

Initial body weight (iBW), average body weight $(\mathrm{aBW})$, final body weight (fBW) and average daily gain (ADG) were determined based on the weighting values.

At the end of the experimental period, the animals were transported to the butchery Frigorífico.

After slaughter, the carcasses were divided, identified, and weighed so as to determine their warm carcass weight (WCw) and warm carcass yield (WCy).

Carcasses were subjected to refrigerated $2^{\circ} \mathrm{C}$ for 24 hours, after; the following aspects have been used for determining the carcass traits:

Loin eye area (LEA): On the right side of the carcass, a cross-section was made between the $12^{\text {th }}$ and $13^{\text {th }}$ ribs and the Longissimus muscle was removed from the carcass.

After removal, the contour was traced invegetable paper and the area was then measured using a planimeter. A "plastic plate" has been used developed by Luchiari Filho (2000).

Loin eye area (LEAwcw): using the equation: (LEA)/(WCw/100)

where: LEA - Loin eye area; WCw - warm carcass weight.

LegLength (LL): Distance in centimeters between the front edge of the pubic bone and the midpoint of the tarsus joint, measured with a metallic caliper. Following this, the distance between the caliper edges was determined with the aid of a measuring tape.

Thigh thickness (TT): With the aid of a metallic calliper, it was possible to measure the distance between the lateral aspect and the medialside of the upper portion. In turn, the distance between the calliper edgeswere afterwards measured using a tape measure. 
Fat cover thickness (FCT): In the cross-sectional area between the $12^{\text {th }}$ and $13^{\text {th }}$ ribs above the Longissimus muscle, this measure formed by the average of three points was calculated with the aid of caliper;

Carcass gain (CG): Ratio between weight gain (kg) and carcass yield (kg per $100 \mathrm{~kg} \mathrm{BW)} \mathrm{obtained}$ by the formula and multiplied by 100 .

The zootechnical indicators used in this work are as follows:initial age (months), age at slaughter (months), initial body weight (kg), final body weight $(\mathrm{kg})$, daily consumption of corn grain ( $\mathrm{kg} /$ animal), daily intake of vitamin mineral protein complex (kg/animal), daily intake ( $\mathrm{kg}$ of diet/animal), daily intake per arroba - 14,688 quilograms - ( $\mathrm{kg}$ of the diet/@), diet cost (US\$/kg of the diet), cost of produced arroba (produced US\$/@) and average price of arroba (US\$) were obtained through data collection during the experiment (Table 2).

Table 2. Zootechnical Indicators used in structuring the models.

\begin{tabular}{|c|c|c|}
\hline \multirow{2}{*}{ Item } & \multicolumn{2}{|c|}{ TREATMENTS } \\
\hline & MALE & FEMALE \\
\hline Initial age (months) & 30 & 24 \\
\hline Period (days) & 70 & 70 \\
\hline Corn intake (kg/animal) & 7.07 & 4.81 \\
\hline Nucleus intake (kg/animal) & 1.25 & 0.85 \\
\hline Todal diet intake (kg/animal) & 8.32 & 5.66 \\
\hline${ }_{\mathrm{I}}^{\mathrm{BW}}(\mathrm{kg})$ & $415.73 \pm 182.0^{*}$ & $274.8 \pm 71.36^{*}$ \\
\hline${ }_{\mathrm{F}} \mathrm{BW}(\mathrm{kg})$ & $491.27 \pm 344.75^{*}$ & $343.3 \pm 172.01^{*}$ \\
\hline aBW(kg) & $453.5 \pm 221.84^{*}$ & $309.05 \pm 104.36^{*}$ \\
\hline Cost of corn (US\$/kg) & 0.21 & 0.21 \\
\hline Cost of nucleus (US\$/kg) & 0.86 & 0.86 \\
\hline Todal diet cost (US\$/kg) & 0.31 & 0.31 \\
\hline Cost of corn (US\$/animal/day) & 1.52 & 1.03 \\
\hline Cost of nucleus (US\$/animal/day) & 1.08 & 0.73 \\
\hline Todal diet cost (US\$/animal/day) & 2.60 & 1.77 \\
\hline Total diet cost (US\$/@) & 65.0 & 56.17 \\
\hline Month the animals were purchased & September & September \\
\hline Purchase cost (US\$/@) & 39.77 & 39.77 \\
\hline Month the animals were sold & November & November \\
\hline Average price per@of finished beef (US\$) & 53.03 & 53.03 \\
\hline
\end{tabular}

${ }_{\mathrm{I}} \mathrm{BW}$ - initial body weight. $\mathrm{BW}-$ final body weight. aBW - average body weight. dollar value of the experimental period (R\$ 1.82$)$. *standard error

Source: Elaboration of the authors.

Economic indicators analyzed in the study:

Average daily gain (ADG; grams) = weight at slaughter - weight at the beginning of the experiment, divided by the experimental period.

Warm carcass yield (WCy $\mathrm{kg} / 100 \mathrm{~kg}$ of body weight $)=$ warm carcass weight $(\mathrm{kg})$ divided by body weight at slaughter $* 100$.

Intake (kgdiet/@) = using the equation: daily intake (kg/day/animal) / average daily gain * 30 .

Diet cost (US\$/animal) $=$ Amount of consumed corn grain multiplied by its purchase price plus the consumed amount of vitamin mineral protein 
nucleus multiplied by its purchase price.

Labor costs plus charges (US\$/@); depreciation and maintenance/improvement costs (US\$/@); Administration costs and taxes (US\$/@)= Average Cost (US\$/@) were obtained from ANUALPEC (2011).

Subtotal (US\$/@) = Sum of costs related to the diet, labor and charges, depreciation and maintenance of improvements, and administration and fees.

Other miscellaneous expenditures (US\$/@) = By multiplying the subtotal per 5\%.

Total cost per arroba (US\$/@) = Sum of the subtotal and other miscellaneous expenses.

Gross income (US\$/@) = Average price of finished beef multiplied by body weight in@ of beef.

Balance (US\$/@) = Gross income minus the total cost(US\$/@) and the acquisition cost of the animal.

Cost-opportunity value of the animal = Acquisition value multiplied by the average percentage of the General index of market prices (GIMP) regarding September, October and November (months of the experiment) in the various productive sectors of the country between 2006 and
2010, according to the Getulio Vargas Foundation.

Net Income (US\$/@) = Balance minus the opportunity cost.

Profitability (US\$levery US\$ 1.00 invested) $=$ Dividingrevenue by the total invested, being expressed as the $\mathrm{R} \$$ paid for each $\mathrm{R} \$ 1.00$ invested.

Profitability in\% a.m. = Net income divided by the invested capital $* 100$, expressed in $\%$ per month.

Results from performance, carcass traits and economic review were subjected to analysis of variance using the "F" test at 0.05 probability in the Sistema de Análises Estatísticas e Genéticas (Statistical and Genetic Analysis System - SAEG 9.1) (RIBEIRO JÚNIOR, 2001).

\section{Results and Discussion}

Weight gain (kg and @), average daily gain (ADG) and carcass gain (GC) did not present differences as a function of $\operatorname{sex}(\mathrm{P}>0.05)$ (Table 3$)$.

The ADG and WG of feedlot cattle were unsatisfactory, since they could have been reached with pasture supplementation (GARCIA et al., 2011) or even with lower concentrate levels (MARCONDES et al., 2011; CLÍMACO et al., 2011; HENRIQUE et al., 2007).

Table 3. Means and standard error for the performance of finished cattle fed grain rich diet and their respective variation coefficients.

\begin{tabular}{lcccc}
\hline \multirow{2}{*}{ Item } & \multicolumn{2}{c}{ Sex } & \multirow{2}{*}{ CV $(\%)$} & \multirow{2}{*}{ P } \\
\cline { 2 - 3 } & MALE & FEMALE & \\
\hline WG $(\mathrm{kg})$ & $75.54 \pm 5.53$ & $6 . .64 \pm 2.31$ & 28.073 & 0.22362 \\
WG (@) & $2.52 \pm 0.18$ & $2.18 \pm 0.08$ & 28.073 & 0.22362 \\
ADG (g) & $1.08 \pm 0.03$ & $0.94 \pm 0.01$ & 28.073 & 0.22362 \\
CG (kg) & $39.11 \pm 14.60$ & $32.87 \pm 15.77$ & 27.750 & 0.13076 \\
FC (kgMS/kgWG) & $8.45 \pm 2.48$ & $5.46 \pm 0.37$ & 30.813 & 0.00165 \\
FD (kgBW/kgDM) & $0.13 \pm 0.0004$ & $0.19 \pm 0.0004$ & 24.096 & 0.00079 \\
\hline
\end{tabular}

IBw - initial body weight; ABw - average body weight; BWs - body weight at slaughter; WG - weight gain; ADG - average daily gain; CG - carcass gain FC- feed conversion FD-feed efficiency.

Source: Elaboration of the authors. 
According to Bianchini et al. (2008), several factors such as weight, age, nutrition, genetics (breed and size or body size), sex, and use of exogenous hormones have affected the growth efficiency of cattle.

he factors described above factors affect the efficiency of beef cattle as to two basic characteristics: rate of gain and chemical composition of the deposited tissues.

Given that the initial body weight was 415.73 and $274.80 \mathrm{~kg}$ for males and females, respectively, one may understand that both sexes were at the finishing phase.

The diet is the main factor, whereas the animals showed signs of subclinical acidosis, as diagnosed bystool staining. The damage to the gastrointestinal tract has probably hindered the good use of nutrients, thus reflecting the performance of the animals.

According to Van Cleef (2009), the use of concentrated diets induces changes in the physiology rumen, since, depending on the food, it may alter the population of microorganisms, the food passing rate, motility and the nutrient absorption rate. These factors can cause a number of metabolic disorders that may result in loss of efficiency and production.

According to Nagaraja and Lechtenberg (2007), this category, fermentative disorders is characterized by changes in the rumen and their activities, resulting in unfavorable conditions for the host. In addition, itcan cause loss of appetite and even death.

Some signs of metabolic disorders associated with acidosis, like rumenite and liver abscesses, were observed at slaughter (OWENS et al., 1998).

Bianchini et al. (2008) have observed ADG values of $1.06 \mathrm{~kg}$ for feedlot Nellore cattle fed grain rich diet $(79 \%$ concentrate) $(1.06 \mathrm{~kg} /$ day $)$. These values are close to the ones found in this study.

Maturana Filho et al. (2010) have reported ADG values of $1.066 \mathrm{~kg}$ in the 84 day treatment with monensin, wherein $70 \%$ of the diet compostion was concentrate. Oliveira et al. (2009) have observed a mean ADG value of $1.44 \mathrm{~kg}$ for feedlot Nelore cattle fed a diet with $60 \%$ concentrate. This percent value was higher than the one found in this study.

Likewise, other authors have observed higher values with lower concentrate levels. This was found to be the case in the study by Sartor Neto et al. (2011), who evaluated grain rich diets (87\%) provided to Nelore cattle and verified higher average daily gains than the ones seen in this study (1.26 kg/day). By assessinga diet containing 79\% concentrate, Missio et al. (2009) have also reported a higher ADG value (1.43 kg/day).

The variables feed conversion (FC) and feed efficiency (FE) were seen to differ between the sexes $(\mathrm{P}<0.05)$. Females had lower feed conversion and increased feed efficiency. This behavior can be explained by a decrease in food intake of females, which is in accordance with the NRC (1996) indicates that the degree of physiological maturity, represented by the proportion of adipose tissue, exerts greater influence on intake, so that for every percentage point increase in body fat, a decrease of $2.7 \%$ in DM intake. In this sense, the heifers at a given age and weight range are physiologically more mature than males castrated and non-castrated, and may have a reduced food intake.

Oliveira et al. (2009) have found a FE value of $0.14 \mathrm{ADGkg} / \mathrm{kg}$ DM forfeedlot finished uncastrated males fed high-grain diet. A similar value was found for the males evaluated in this study.

Sex was seen to affect the carcass traits: thick thickness (TT), leg length (LL), fat cover thickness (FCT), loin eye area (LEA), warm carcass weight (WCW) and carcass yield $(\mathrm{CW})(\mathrm{P}<0.05)$, except for the variable "loin eye area" corrected for $100 \mathrm{~kg}$ of HCW $(\mathrm{P}<0.05)$ (Table 4). 
Table 4. Means and standard error for the carcass traits of finished cattle fed grain rich diet. and their respective variation coefficients.

\begin{tabular}{lcccc}
\hline \multirow{2}{*}{\multicolumn{1}{c}{ Item }} & \multicolumn{2}{c}{ Sex } & \multirow{2}{*}{ CV $(\%)$} & \multirow{2}{*}{ P } \\
\cline { 2 - 3 } & MALE & FEMALE & \\
\hline TT $(\mathrm{cm})$ & $26.33 \pm 0.595$ & $22.88 \pm 0.455$ & 6.456 & 0.0003 \\
LL $(\mathrm{cm})$ & $82.88 \pm 0.754$ & $74.88 \pm 0.721$ & 2.804 & 0.0001 \\
FCT $(\mathrm{mm})$ & $1.83 \pm 0.083$ & $2.88 \pm 0.232$ & 22.182 & 0.0005 \\
LEA $\left(\mathrm{cm}^{2}\right)$ & $75.67 \pm 26.41$ & $56.33 \pm 8.18$ & 11.478 & 0.0000 \\
LEA $_{\text {wCw }}\left(\mathrm{cm}^{2}\right)$ & $29.95 \pm 6.67$ & $32.96 \pm 3.39$ & 12.955 & 0.0811 \\
WCW $(\mathrm{kg})$ & $254.40 \pm 107.46$ & $171.41 \pm 28.70$ & 7.062 & 0.0000 \\
CY $(\mathrm{kg} \mathrm{per} \mathrm{100} \mathrm{kg} \mathrm{of} \mathrm{CW})$ & $51.76 \pm 0.07$ & $50.19 \pm 0.91$ & 2.803 & 0.0118 \\
\hline
\end{tabular}

TT - thick thickness; LL - leg length; FCT - fat cover thickness; LEA. loin eye area; LEAWCW - loin eye area corrected for $100 \mathrm{~kg}$ of warm carcass weight; HCW - warn carcass weight; CY - carcass yield.

Source: Elaboration of the authors.

The differences observed for LL and TT can be justified by the fact thatthe animals were at the same physiological stage (termination). Uncastrated males have shown a higher body structure, particularly as regard sheight and width, which are parameters determined by sex.

Carcass traits are extremely important, since they indicate the percentage of carcass meat and how they it is distributed.

Due to earlier fat deposition, females showed higher FCT indexes than uncastrated males.Females show an earlier fat deposition than castrated males, the latter being more precocious than uncastrated males (LUCHIARI FILHO, 2000). The meat of steerstherefore tends to have lower quality.

Sartor Neto et al. (2011) have observed average values of 5.03 and $3.38 \mathrm{~mm}$ in uncastrated Nellore animals. These values are close to the ones found in this study.The authors highlight that both subcutaneous fat thickness (SFT) and fat cover depend upon genetic factors associated with feeding management and nutritional requirements (BIANCHINI et al., 2008).

Despite this diet is of the highest quality, the animals could not respond as efficiently due to the overall adaptation to it. Thus, the performance responses were reduced and other variables such as fat deposition were compromised.

According to Ladeira and Oliveira (2006), the first effect of animal nutrition on the quality of beef concerns dry matter intake (DMI).Animals that do not have metabolic disorders but that have a high intake of dry matter show high growth rates and thereby greater fat deposition.

The average FCT had unsatisfactory values, as both sexes were below the critical point of $3 \mathrm{~mm}$.

The optimum range FTC is between 3 and 6 $\mathrm{mm}$, i.e., the values were below this range. When subjected to cooling, a darkening occurs on the outer region overlying the carcass, whereas the muscle fibers are shortened by the low temperature, affecting the beef tenderness and color.

In the evaluation of diets containing 22-79\% concentrate, Missio et al. (2010) have found that the minimum carcass length requirement was met (3 $\mathrm{mm})$.

The observed effect in thevariable LEA was due to carcass size differences mainly provoked by chronologicaldisparities.

Machado Neto et al. (2011) have evaluated the carcass traits of uncastrated Nellore steers raised under confinement and found average LEA values of $68.67 \mathrm{~cm}^{2}$. The value found was near the above 
mentionded. Furthermore, this variable is related to nutrition and age.

In the analysis of feedlot Nellore cattlefed diets containing high grain proportions $(79 \%$ and $87 \%$, respectively), Missio et al. (2010) and Sartor Neto et al. (2011) have verified WCY values higher than the ones found in this study (58.26\% and 55.65\%).

In addition to taxes, personnel, depreciation, improvements and administration-related costs were not seen to vary as a function of sex $(\mathrm{P}>0.05)$. In assessing the finishing of Nellore cattle raised under confinement, Lopes et al. (2011) have found lower values for labor (R\$1.59/@) and depreciation (R\$1.52/@), assuming that such lower labor- and depreciation-related costs could have resulted from the fact that the authors used 41 animals in their study, extrapolating the data relating to 120 animals and "diluting" the addressed items (Table 5).

The low cost of depreciation of leasehold improvements due to the low investment required for the facilities.

The subtotal has varied as a function of sex $(\mathrm{P}<0.05)$, probably because of different food expenses (243 vs. 157 kg of the diet by @), as the other items comprising the subtotal were similar between sexes. This has been evidenced by feed conversion, whereas males showed about 54.76\% difference. Thus, there has been a significant increase in the amount of food spent for expressing the same potential gain of females, increasing the feeding costs. Lopes et al. (2011) state that this must be a major concern of breeders.

Other expenses were justified by differences as a function of sexes, as a result from the fact that this variable is used to cover extra expenses that may arise throughout the production cycle. Hence, a common percentage was considered for both sexes (5\%), on the basis of the subtotal cost of arroba. Once the subtotal of males was higher than the one of females, the other expenses followed the same trend.

Table 5. Mean and standard error of the economic feasibility of feedlot cattle fed high grain diets. and their variation coefficients.

\begin{tabular}{|c|c|c|c|c|}
\hline \multirow{2}{*}{ Item } & \multicolumn{2}{|c|}{ TREATMENT } & \multirow{2}{*}{$\mathrm{CV}(\%)$} & \multirow{2}{*}{$\mathrm{P}$} \\
\hline & MALE & FEMALE & & \\
\hline Labor-related costs (US\$/@) & 2.44 & 2.69 & 28.988 & $* * * * * *$ \\
\hline Depreciation and improvements-related costs (US\$/@) & 1.06 & 1.15 & 28.988 & $* * * * * *$ \\
\hline Administration costs and fees (US\$/@) & 2.02 & 2.22 & 28.988 & $* * * * * *$ \\
\hline Subtotal (R\$/animal) & 222.96 & 134.02 & 5.780 & 0.0000 \\
\hline Miscellaneous expenses (US\$/animal) & 11.15 & 6.70 & 5.780 & 0.0000 \\
\hline Total costs $(\mathrm{R} \$ /$ animal $)$ & 234.10 & 140.72 & 5.780 & 0.0000 \\
\hline Gross income (US\$/animal) & 899.54 & 606.10 & 7.062 & 0.0000 \\
\hline Balance (US\$/animal) & 114.19 & 99.04 & 32.735 & 0.2886 \\
\hline Opportunity value GMPI (US\$ animal) & 13.19 & 8.52 & 5.900 & 0.0000 \\
\hline Net revenue (US\$/animal) & 100.99 & 90.52 & 36.349 & $* * * * * *$ \\
\hline Profitability (US\$/R\$1.00 invested) & 0.62 & 0.65 & 4.801 & 0.0345 \\
\hline Profitability (\% month) & 5.42 & 7.57 & 35.855 & 0.0345 \\
\hline
\end{tabular}

Dollar value of the experimental period $(\mathrm{R} \$ 1.82)$.

Source: Elaboration of the authors. 
The total cost of males was higher than that of females $(\mathrm{P}<0.05)$. In addition, there has been an increase of $65.52 \%$ in the cost, which is a high variation that may even define whether the confinement system is sustainable or not. This is due to the high feed conversion ( 8.45 vs. 5.46), which greatly increases feeding costs.

Gross income, balance, opportunity cost and net income were on average higher for males $(\mathrm{P}<0.05)$. Nevertheless, this difference in gross income is a result of higher body weight in males at slaughter. Above all, it is worth highlighting that the amount received per@(R\$ 52,72) in both sexes was attractive when compared to the prices offered the region, thus maximizing the system's gross income.

Lopes et al. (2011) sustains that the success of the feedlot activity depends upon two aspects selling price and the cost of animal feed.

One of the major disadvantages of feedlot systems is the inherent economic risk. Added to that, one must consider the fact that the preliminary economic evaluation is merely speculative, i.e., the financial return is based on both bid and ask values. Speculations can therefore be prevented by way of future purchasing and selling contracts. According to ANUALPEC (2011), there should be a sensitivity analysis aimed at asssessing the risks of each proposed system, considering possible market variations.

Yet, in some cases, confinement may be the best solution in order to prevent major losses on the farm.

According to Oliveira Neto and Figueiredo (2008), the difficult of beef cattle producers in dealing with uncertain financial scenarios in the physical market, as well as the real need to protect themselves against constant price fluctuations reveals the importance of hedging contracts in futures markets.

As for the balance, the authors highlight that, despite males have an acquisition cost 50.47\% above that of females (R\$548.21 vs R\$ 364.34), the gross income of males was also $48.41 \%$ higher than the females'. Because the opportunity cost was calculated by multiplying the capital assetby the average price index (GMPI), considering both data during the confinement period (SeptemberNovember). The opportunity cost of males, in turn, was higher due to the elevated capital asset per animal, taking into consideration that the finishing body weight of males is higher than the female's.

Profitability showed no differences as a function of sex $(\mathrm{P}<0.05)$. The net income of males was higher than the one of females; this similarity in profitability is justified by the fact that this variable is relative, once the net revenue is an absolute variable. Hence, the lowest net revenue of females became economically similar when yield was realizedon the basis of the invested capital.

Profitability follows the same trend of yield, being justifiedby the same reasons, and similar in both sexes $(\mathrm{P}<0.05)$. Nevertheless, the variable referring to profitability has addressed percentage values, helping in the understanding and analysis, in particular when compared to other productive sectors. Despite the production cost was higher than the acquisition cost of arroba, profitability and positive profit are consequences of the tradevalue premium $(33.3 \%)$ on the amount received per arroba at slaughter. That being said, it is noteworthy that sustainability is only made possible with the inclusion of a representative premium during the period of confinement.Furthermore, it should be noted that confinement confers an indirect advantage, which is the provision of grazing areas to other categories.

The profitability of feedlot finishing cattle may varyas it is influenced by changes imposed by the market on the prices of raw materials and end product. This variability can be clearly seen in different regions of the country, as the supplies and meat products respond to market changes on a regional basis (MISSIO et al., 2009).

With respect to the monthly profitability of 
feedlot cattle, the national literature shows both negative values, like - $9.97 \%$ for Red Norte, $31.14 \%$ for Nellore (LOPES et al., 2011) and positive values such as $0.1 \%$ for crossbred Charolais/ Nellore (MISSIO et al., 2009), 0.12\% for crossbred Red Angus/Nellore and Aberdeen Angus/Nellore (FERREIRA et al., 2009), 3.8\% for Nellore (COAN et al., 2008) and 4.1\% for Red Angus (RESTLE; PACHECO; COSTA, 2007).

Because the feedlot system increases the capacity utilization of the farmand consequently increases productivity (weight gain per hectare), possibly increasing the profitability and the working capital, this sytem cannot be evaluated in isolation, furthermore, the removal of heavier cattle (finishing phase) increases the overall forage availability for other livestock categories and/or reduces the number of animal sin early spring, thereby increasing their productivity at the beginning of summer. Aside from that, this measure reducing the expenses on renewing pastures.

Another noteworthy factor is the reduction of production cycles, reducing the use of forage resources at strategic times when forage availability is low and lowering the average slaughter age, which is translated into beef products of better quality.

Above what had been expected, there have been increasingly prolonged periods of drought in northestern Brazil. Farms very often lack greater forage stocks in the form of hay or silage. Forage supply is therefore the biggest problem on the farms. Long droughtscan make forage stocks even more scarce than the concentrate, making it more expensive, and making the system unfeasible both regarding the price of forage and the animal's weight loss.

The intensive system of meat production is in this case represented by the fattening of feedlot animals and brings positive results, reinforcing that the activity can be profitable. Further studies are yet necessary so as to assess the production system, once cattle finishing may generate indirect benefits, such as increased productivity, reduction of fixed costs, higher availability of pastures for other animals, and use of new technologies (FERNANDES et al., 2008).

Whereas the variability of genetic potential plays an important role in animals from the same breed, a strict selection of animals is requiredin order to achieve best possible results on feedlot systems (RESTLE; PACHECO; COSTA, 2007).

\section{Conclusions}

Males and females have the same performance when fed diets high grain, however females have better fat cover. Use of male and female high grain in feedlots are economically viable.

\section{References}

ANUÁRIO DA PECUÁRIA BRASILEIRA ANUALPEC. São Paulo: Instituto FNP. 2011. 334 p.

BERG, R. T.; BUTTERFIELD, R. M. New concepts of cattle growth. Sydney: Sydney University, 1976. 240 p.

BIANCHINI, W.; SILVEIRA, A. C.; ARRIGONI, M. B.; JORGE, A. M.; MARTINS, C. L.; RODRIGUES, E. Crescimento e características de carcaça de bovinos superprecoces Nelore. Simental e mestiços. Revista Brasileira de Saúde e Produção Animal, Salvador, v. 9, n. 3, p. 554-564, 2008.

CAPPELLE, E. R.; VALADARES FILHO, S. C.; SILVA, J. F. C.; CECON, P. R. Estimativas do valor energético a partir de características químicas e bromatológicas dos Alimentos. Revista Brasileira de Zootecnia, Viçosa, MG, v. 30, n. 6, p. 1837-1856, 2001.

CASALI, A. O.; DETMANN, E.; VALADARES FILHO, S. C.; PEREIRA, J. C.; HENRIQUES, L. T.; FREITAS, S. G.; PAULINO, M. F. Influência do tempo de incubação e do tamanho de partículas sobre os teores de compostos indigestíveis em alimentos e fezes bovinas obtidos por procedimentos in situ. Revista Brasileira de Zootecnia, Viçosa, MG, v. 37, n. 2, p. 335-342, 2008.

CLÍMACO, S. M.; RIBEIRO, E. L. de A.; MIZUBUTI, I. Y.; ROCHA, M. A. da; SILVA, L. das D. F. da; PEREIRA, E. S. Desempenho e características de carcaça de bovinos de corte de quatro grupos genéticos terminados em confinamento. Revista Brasileira de Zootecnia, Viçosa, MG, v. 40, n. 7, p. 1562-1567, 2011. 
COAN, R. M.; REIS, R.A.; RESENDE, F. D.; SAMPAIO, R. L.; SCHOCKEN-ITURRINO, R. P.; GARCIA, G. R.; BERCHIELLI, T. T. Viabilidade econômica, desempenho e características de carcaça de garrotes em confinamento alimentados com dietas contendo silagem de capins tanzânia ou marandu ou silagem de milho. Revista Brasileira de Zootecnia, Viçosa, MG, v. 37, n. 2, p. 311-318, 2008.

FERNANDES, A. R. M.; SAMPAIO, A. A. M.; HENRIQUE, W.; PERECIN, D.; OLIVEIRA, E. A.; TÚLLIO, R. R. Avaliação econômica e desempenho de machos e fêmeas Canchim em confinamento alimentados com dietas à base de silagem de milho e concentrado ou cana-de-açúcar e concentrado contendo grãos de girassol. Revista Brasileira de Zootecnia, Viçosa, MG, v. 36, n. 4, p. 855-864, 2008.

FERREIRA, I. C.; SILVA, M. A.; BARBOSA, F. A.; CARVALHO, A. D. F.; CORREA, G. S. S.; FRIDRICH, A. B.; SOUZA, J. E. R. Avaliação técnica e econômica de diferentes grupos genéticos de bovinos de corte machos superprecoces e do sistema de produção em confinamento. Arquivo Brasileiro de Medicina Veterinária e Zootecnia, Belo Horizonte, v. 61, n. 1, p. 243-250, 2009.

GARCIA, C. S.; FERNANDES, A. M.; FONTES, C. A. A.; VIEIRA, R. A. M.; SANT'ANNA, N. F.; PIMENTEL, V. A. Desempenho de novilhos mantidos em pastagens de capim-elefante e capim-mombaça. Revista Brasileira de Zootecnia, Viçosa, MG, v. 40, n. 2, p. 403-410, 2011.

HALL, M. B. Challenges with non-fiber carbohydrate methods. Journal of Animal Science, Champaign, v. 81, n. 12, p. 3226-3232, 2003.

HENRIQUE, W.; BELTRAME FILHO, J. A.; LEME, P. R.; LANNA, D. P. D.; ALLEONI, G. F.; COUTINHO FILHO, J. L.; SAMPAIO, A. A. M. Avaliação da silagem de grãos de milho úmido com diferentes volumosos para tourinhos em terminação: desempenho e características de carcaça. Revista Brasileira de Zootecnia, Viçosa, MG, v. 36, n. 1, p. 183-190, 2007.

LADEIRA, M. M.; OLIVEIRA, R. L. Estratégias nutricionais para melhoria da carcaça bovina In: SIMBOI - SIMPÓSIO SOBRE DESAFIOS E NOVAS TECNOLOGIAS NA BOVINOCULTURA DE CORTE, 2., 2006, Brasília. Anais... Brasília: Faculdades Integradas, UPIS, 2006. p. 45-56.

LOPES, L. S.; LADEIRA, M. M.; MACHADO NETO, O. R.; SILVEIRA, A. R. M. C. da; REIS, R. P. CAMPOS, F. R. Viabilidade econômica da terminação de novilhos nelore e Red norte em confinamento na região de Lavras - MG. Ciência e Agrotecnologia, Lavras, v. 35, n. 4, p. 774-780, 2011.
LUCHIARI FILHO, A. A pecuária da carne bovina. São Paulo: Luchiari Filho, 2000. 134 p.

MACHADO NETO, O. R.; LADEIRA, M. M.; GONÇALVES, T. M.; LOPES. L. S.; OLIVEIRA, D. M.; LIMA, R. R. Performance and carcass traits of Nellore and Red Norte steers finished in feedlot. Revista Brasileira de Zootecnia, Viçosa, MG, v. 40, n. 5, p. 10801087, 2011.

MARCONDES, M. I.; VALADARES FILHO, S. C.; OLIVEIRA, I. M.; PAULINO, P. V. R.; VALADARES, R. F. D.; DETMANN, E. Eficiência alimentar de bovinos puros e mestiços recebendo alto ou baixo nível de concentrado. Revista Brasileira de Zootecnia, Viçosa, MG, v. 40, n. 6, p. 1313-1324, 2011.

MATURANA FILHO, M.; OLIVEIRA, M. G.; SARAN NETTO,A.; ZANETTI, M.A.; CORREA, L. B.; CLARO, G. R. Parâmetros sanguíneos e desempenho de bovinos de corte em confinamento submetidos a diferentes fontes de ionóforos. Revista Brasileira de Saúde e Produção Animal, Salvador, v. 11, n. 3, p. 772-782, 2010.

MISSIO, R. L.; BRONDANI, I. L.; ALVES FILHO, D. C.; RESTLE, J.; ARBOITTE, M. Z.; SEGABINAZZI, L. R. Características da carcaça e da carne de tourinhos terminados em confinamento. recebendo diferentes níveis de concentrado na dieta. Revista Brasileira de Zootecnia, Viçosa, MG, v. 39, n. 7, p. 1610-1617, 2010.

MISSIO, R. L.; BRONDANI, I. L.; FREITAS, L. S.; SACHET, R. H.; SILVA, J. H. S.; RESTLE, J. Desempenho e avaliação econômica da terminação de tourinhos em confinamento alimentados com diferentes níveis de concentrado na dieta. Revista Brasileira de Zootecnia, Viçosa, MG, v. 38, n. 7, p. 1309-1316, 2009.

NAGARAJA, T. G.; LECHTENBERG, K. F. Acidosis in feedlot cattle. Veterinary Clinics of Food Animals, Philadelphia, v. 23, n. 2, p. 333-350, 2007.

NATIONAL RESEARCH COUNCIL - NRC. National science education standards: observe, interact, change, learn. Washington, D.C.: National Academy Press, 1996. 243 p.

OLIVEIRA NETO, O. J.; FIGUEIREDO, R. S. Análise das operações de hedge do boi gordo no mercado futuro da BM \& F para o estado de Goiás. Revista Gestão e Planejamento, Goiânia, v. 9, n. 6, p. 77-93, 2008.

OLIVEIRA, E. A.; SAMPAIO, A. A. M.; FERNANDES, A. R. M.; HENRIQUE, W.; OLIVEIRA, R. V.; RIBEIRO, G. M. Desempenho e características de tourinhos Nelore e Canchim terminados em confinamento recebendo dietas com cana-de-açúcar e dois níveis de concentrado. Revista Brasileira de Zootecnia, Viçosa, MG, v. 36, n. 12, p. 2465-2472, 2009. 
OWENS, F. N.; SECRIST, D. S.; HILL, W. J.; GILL, D. R. Acidosis in cattle a review. Journal Animal Science, Oklahoma, v. 76, n. 1, p. 275-286, 1998.

PAULINO, P. V. R.; VALADARES FILHO, S. C.; DETMANN, E. Deposição de tecidos e componentes químicos corporais em bovinos Nelore de diferentes sexos. Revista Brasileira de Zootecnia, Viçosa, MG, v. 38, n. 12, p. 2516-2524, 2009.

RESTLE, J.; PACHECO, P. S.; COSTA, E. C. Apreciação econômica da terminação em confinamento de novilhos Red Angus superjovens abatidos com diferentes pesos. Revista Brasileira de Zootecnia, Viçosa, MG, v. 36, n. 4, p. 978-986, 2007.

RIBEIRO JÚNIOR, J. I. Análises estatísticas no SAEG: sistema para análises estatísticas. Viçosa, MG: UFV, $2001.301 \mathrm{p}$.

SARTOR NETO, A.; RIBEIRO, E. L. A.; MIZUBUTI, I. Y.; PEREIRA, E. Z.; CUNHA, G. E.; SILVA, L. D. F.; BARBOSA, M. A. A. F.; BUMBIERIS JUNIOR, V. H. Desempenho e características de carcaça de bovinos Nelore confinados recebendo dietas de alto teor de concentrado com diferentes níveis de tanino. Semina: Ciências Agrárias, Londrina, v. 32, n. 3, p. 1179-1190. 2011.
SILVA, D. J.; QUEIROZ, A. C. Análise de alimentos: métodos químicos e biológicos. 3. ed. Viçosa, MG: UFV, 2002. $235 \mathrm{p}$.

SILVA, R. R.; PRADO, I. N.; CARVALHO, G. G. P.; SILVA, F. F.; ALMEIDA, V. V. S.; SANTANA JUNIOR, H. A.; ABREU FILHO, G. Níveis de suplementação na terminação de novilhos Nelore em pastagens: aspectos econômicos. Revista Brasileira de Zootecnia, Viçosa, MG, v. 39, n. 9, p. 2091-2097, 2010.

SNIFFEN, C. J.; O'CONNOR, J. D.; VAN SOEST, P. J.; FOX, D. G.; RUSSELL, J. B. A net carbohydrate and protein system for evaluating cattle diets: IICarbohydrate and protein availability. Journal of Dairy Science, Madison, v. 70, n. 1, p. 3562-3577, 1992.

VAN CLEEF, H. E.; NEIVA, P. A.; SERAFIM, S. R.; ANIBAL REGO, C. A.; GONÇALVES, G. Distúrbios metabólicos por manejo alimentar inadequado em ruminantes: novos conceitos. Revista Colombiana Ciência Animal, Sincelejo, v. 1, n. 2, p. 319-341, 2009. 